\title{
Peran Pendidikan Agama dan Kewarganegaraan di SMA Dalam Meningkatkan Karakter Tangguh, Kompetitif dan Dinamis
}

\author{
Antonina Pantja Juni Wulandari \& Astrini \\ Jurusan Psikologi \\ Universitas Bina Nusantara \\ Jl. Kemanggisan Ilir III No.45, Palmerah, Jakarta Barat \\ yunwulan@binus.edu \&astrini_0306@yahoo.com
}

\begin{abstract}
The research looked at the role of religious and citizenship educations acquired during high school in improving the characters in particular tough, competitive, and dynamic. The study was conducted on 100 freshmen at Binus University based on their perceptions of Religious and Citizenship education that they acquired during High School in improving tough, competitive, and dynamic characters. The results showed that they have all three characters, but the intensity is not strong and there was no significant relationship between perceptions of the two subjects with the characters. This suggests that student's characters, tough, competitive and dynamic, are not based on whether they perceive the two subjects as pleasant or unpleasant. The formation of the characters in particular, tough, competitive and dynamic characters, can develop due to the circumstances of the school as a whole and not specifically through the subjects of Religious and Citizenship Educations.
\end{abstract}

Keywords: character, persistence, competitive

\begin{abstract}
Abstrak-Penelitian ini melihat peranan pendidikan agama dan kewarganegaraan yang didapat siswa selama di SMA dalam meningkatkan karakter terutama karakter tangguh, kompetitif, dan dinamis. Penelitian dilakukan pada mahasiswa yang baru masuk di Binus University sebanyak 100 orang, dengan melihat persepsi pelajaran Pendidikan Agama dan Kewarganegaraan dalam meningkatkan karakter tangguh, kompetitif, dan dinamis. Hasil penelitian menunjukkan bahwa mereka memiliki ketiga karakter tersebut namun intensitas yang ada tidak terlalu kuat dan tidak ada hubungan yang signifikan antara persepsi terhadap kedua mata pelajaran tersebut dengan karakternya. Hal ini menunjukkan bahwa peserta didik tetap memiliki karakter tangguh, kompetitif dan juga dinamis tidak berdasarkan apakah mereka mempersepsikan kedua mata pelajaran tersebut menyenangkan atau tidak menyenangkan. Karena pembentukan karakter khususnya karakter tangguh, kompetitif dan dinamis dapat saja berkembang dengan baik dikarenakan oleh situasi dan kondisi sekolah secara keseluruhan dan bukan secara khusus melalui mata pelajaran Pendidikan Agama dan Pendidikan Kewarganegaraan.
\end{abstract}

Kata kunci: karakter, tangguh, kompetitif 


\section{PENDAHULUAN}

\section{Latar Belakang Penelitian}

Memperhatikan situasi dan kondisi karakter bangsa yang memprihatinkan dengan masih besar kesenjangan sosial-ekonomi-politik, kerusakan lingkungan yang terjadi di berbagai di seluruh pelosok negeri, masih terjadinya ketidakadilan hukum, pergaulan bebas dan pornografi yang terjadi di kalangan remaja, kekerasan dan kerusuhan, korupsi dan yang merambah pada semua sektor kehidupan masyarakat. Banyaknya dijumpai tindakan anarkis, konflik sosial, penuturan bahasa yang buruk dan tidak santun, dan ketidaktaatan berlalu lintas. Pemerintah mengambil inisiatif untuk memprioritaskan pembangunan karakter bangsa (Bappenas, 2013) .

Dalam Rencana Pembangunan Jangka Panjang Nasional Tahun 2010-2025 (Pemerintah RI, 2010), pembangunan karakter bangsa menjadi arus utama pembangunan nasional. Artinya, setiap upaya pembangunan harus selalu dipikirkan keterkaitan dan dampaknya terhadap pengembangan karakter. Hal itu tercermin dari misi pembangunan nasional yang memposisikan pendidikan karakter sebagai misi pertama dari delapan misi guna mewujudkan visi pembangunan nasional, sebagaimana tercantum yaitu terwujudnya karakter bangsa yang tangguh, kompetitif, berakhlak mulia, dan bermoral berdasarkan Pancasila, yang dicirikan dengan watak dan perilaku manusia serta masyarakat Indonesia yang beragam, beriman dan bertakwa kepada Tuhan Yang Maha Esa. Pembangunan karakter bangsa berfungsi membentuk dan mengembangkan potensi manusia atau warga negara Indonesia agar berpikiran baik, berhati baik, dan berperilaku baik sesuai dengan falsafah hidup Pancasila.

Pemerintah dalam Kebijakan Nasional Pembangunan Karakter Bangsa Tahun 2010-2025 mencanangkan pembangunan karakter bangsa dilakukan melalui pendekatan sistematik dan integratif dengan melibatkan keluarga; satuan pendidikan; pemerintah; masyarakat termasuk teman sebaya, generasi muda, lanjut usia, media massa, pramuka, organisasi kemasyarakatan, organisasi politik, organisasi profesi, lembaga swadaya masyarakat; kelompok strategis seperti elite struktural, elite politik, wartawan, budayawan, agamawan, tokoh adat, serta tokoh masyarakat. Adapun strategi pembangunan karakter dilakukan melalui sosialisasi, pendidikan, pemberdayaan, pembudayaan, dan kerja sama dengan memperhatikan kondisi lingkungan dan kebutuhan masyarakat serta pendekatan multidisiplin yang tidak menekankan pada indoktrinasi.

Salah satu strategi tersebut di atas tertuang dalam Kebijakan Nasional Pembangunan Karakter Bangsa Tahun 2010-2025 (Pemerintah RI, 2010) pendidikan karakter bangsa yang terintegrasi di dalam mata pelajaran adalah pengenalan nilai-nilai, diperolehnya kesadaran akan pentingnya nilai-nilai, dan penginternalisasian nilai-nilai ke dalam tingkah laku peserta didik sehari-hari melalui proses pembelajaran, baik yang berlangsung di dalam maupun di luar kelas pada semua mata pelajaran. Pada dasarnya kegiatan pembelajaran, selain untuk menjadikan peserta didik menguasai kompetensi (materi) yang ditargetkan, juga dirancang untuk menjadikan peserta didik mengenal, menyadari/peduli, dan menginternalisasi nilai-nilai dan menjadikannya perilaku. Sehingga siswa memiliki karakter tangguh, kompetitif, berakhlak mulia, bermoral, bertoleran, bergotong royong, patriotik, dinamis, berbudaya, dan berorientasi Ipteks berdasarkan Pancasila dan dijiwai oleh iman dan takwa kepada Tuhan Yang Maha Esa.

Pendidikan karakter sebaiknya diajarkan secara eksplisit daripada secara tertutup (hidden curriculum), artinya pendidikan karakter ada upaya yang teratur dan terarah, yang dilakukan dalam bentuk program yang direncanakan dan diterapkan secara konsisten serta terus-menerus berkesinambungan dan terintegrasi 
satu sama lain (Milson dan Mehlig, 2002). Pada pendidikan menengah, secara umum pendidikan karakter dilaksanakan dengan menggunakan pendekatan terintegrasi dalam semua mata pelajaran. Secara khusus, dilakukan pada mata pelajaran Pendidikan Agama dan Pendidikan Kewarganegaraan. Dalam kedua mata pelajaran tersebut, karakter dikembangkan sebagai dampak pembelajaran dan juga dampak pengiring. Sementara itu mata pelajaran lainnya, yang secara formal memiliki misi utama selain pengembangan karakter, wajib mengembangkan rancangan pembelajaran pendidikan karakter yang diintegrasikan ke dalam substansi/kegiatan mata pelajaran sehingga memiliki dampak pengiring bagi berkembangnya karakter dalam diri peserta didik. Harapan dari pelaksanaan pendidikan karakter di Sekolah Menengah adalah setiap peserta didik dapat menginternalisasikan nilai-nilai yang diajarkan serta menunjukkan kekonsistensian perilaku yang menunjukkan karakter yang dimilikinya. Karakter tangguh, kompetitif dan dinamis merupakan beberapa karakter yang diharapkan oleh pemerintah dimiliki oleh setiap siswa setelah mengenyam pendidikan (KEMDIKNAS, 2010).

Karakter tangguh, kompetitif dan dinamis ini secara umum dapat membantu peserta untuk menjalani aktivitas sehari-hari dan juga untuk menyatu dan bersosialisasi dengan masyarakat di sekitarnya. Secara khusus, setelah mengenyam pendidikan di sekolah menengah peserta didik banyak yang melanjutkan pendidikannya ke perguruan tinggi, karakter yang telah dibangun akan sangat membantu peserta didik untuk menghadapi kegiatan dan penyesuaian dirinya dalam lingkungan pendidikan yang baru. Stoltz (2000), ketangguhan adalah konsep yang menentukan kesuksesan individu yang terbentuk sepanjang masa kehidupan, dan dapat dikembangkan. Kurikulum sekolah hendaknya mendorong siswa memiliki ketangguhan yang tinggi untuk meraih sukses hidup. Saurina \& Pandia (2012), penelitian mereka tentang dampak kurikulum terhadap ketangguhan siwa yang dilakukan, didapatkan gambaran ketangguhan terbanyak ada di kategori rendah $72 \%$, kategori sedang $27 \%$, dan siswa dengan kategori tinggi $1 \%$.

Dari hasil penelitian di atas yang menggambarkan banyaknya siswa yang masuk dalam kategori rendah, menunjukkan kemampuan siswa menghadapi masalah, dan meraih kesuksesannya atau kemampuan kompetitifnya juga rendah. Padahal banyak perubahan dari sekolah menengah ke jenjang perguruan tinggi di mana terdapat jadwal, aktivitas dan peran yang berubah dibandingkan dengan rutinitas pada sekolah menengah. Peserta didik di perguruan tinggi akan bertemu dengan lebih banyak individu dengan latar belakang berbeda-beda dan juga dengan tujuan pendidikan yang berbeda pula. Selain itu, pertemanan dan hubungan sosial dengan teman sebaya juga mengalami perubahan di mana masing- masing mahasiswa memiliki kebiasaan, karakternya dan nilai-nilai yang dianutnya masing-masing.

Sebagai mahasiswa, peserta didik tidak hanya dituntut untuk dapat menyesuaikan diri dengan tuntutan akademik saja namun juga untuk dapat menyesuaikan diri dengan kegiatan-kegiatan non akademik yang dapat mendukungnya mengembangkan diri. Diharapkan setelah mendapatkan pendidikan karakter khususnya melalui mata pelajaran Pendidikan Agama dan Pendidikan Kewarganegaraan para peserta didik dapat terbantu untuk menghadapi tantangan sebagai mahasiswa baru. Melihat fenomena dan tantangan yang dihadapi oleh peserta didik setelah lulus dari sekolah menengah dan memasuki pendidikan lanjutan di perguruan tinggi maka tim peneliti tertarik untuk melihat gambaran karakter mahasiswa semester satu Jurusan Psikologi Binus University, agar hasil dari penelitian ini dapat membantu dalam pembentukan program pendidikan karakter di Binus University. 


\section{Tujuan Penelitian}

Penelitian ini bertujuan untuk melihat gambaran karakter mahasiswa semester 1 yang mendapatkan mata pelajaran Pendidikan Agama dan Pendidikan Kewarganegaraan di sekolah menengah yang bertujuan mendidik karakter siswa untuk menjadi lebih tangguh, kompetitif, dan dinamis berdasarkan Pancasila dan dijiwai oleh iman dan takwa kepada Tuhan Yang Maha Esa.

\section{Manfaat Penelitian}

Penelitian ini bermanfaat untuk memberikan gambaran secara menyeluruh mengenai karakter tangguh, kompetitif dan dinamis dari mahasiswa semester 1 yang baru saja menyelesaikan pendidikannya di sekolah menengah. Selain itu, penelitian ini juga bermanfaat untuk menjadi penelitian awal mengenai karakter yang dibentuk selama peserta didik mengenyam pendidikan sampai jenjang pendidikan menengah. Selanjutnya dapat dibuat penelitian lanjutan dan pengembangan karakter untuk mahasiswa semester awal.

\section{Tinjauan Pustaka}

Dalam Kebijakan Nasional Pembangunan Karakter Bangsa tahun 2010-2025 (Pemerintah RI, 2010) menyebutkan karakter sebagai nilai-nilai yang khas-baik (tahu nilai kebaikan, mau berbuat baik, nyata berkehidupan baik, dan berdampak baik terhadap lingkungan) yang terpateri dalam diri dan terejawantahkan dalam perilaku. Karakter secara koheren memancar dari hasil olah pikir, olah hati, olah raga, serta olah rasa dan karsa seseorang atau sekelompok orang. Karakter merupakan ciri khas seseorang atau sekelompok orang yang mengandung nilai, kemampuan, kapasitas moral, dan ketegaran dalam menghadapi kesulitan dan tantangan.

Karakter bukan sekadar hasil dari sebuah tindakan melainkan secara simultan merupakan hasil dan proses (Santrock, 2008). Koesoema (2007) mengatakan bahwa pengembangan karakter merupakan proses terus-menerus, karakter bukanlah kenyataan, melainkan keutuhan perilaku, karakter bukan hasil atau produk melainkan usaha hidup. Berkowitz dan Bier (2004), karakter merupakan seperangkat karakteristik psikologis yang sifatnya kompleks serta memungkinkan individu untuk berperilaku sebagai agen moral. Lickona (2004) menggambarkan bahwa karakter adalah sesuatu yang terlihat. Lebih jauh ia menjelaskan bahwa karakter terdiri dari sifat-sifat baik sebagai bentuk dari perilaku yang sesuai moral. Dengan demikian dapat dikatakan bahwa karakter merupakan bentuk konkret, atau penerapan dari moral. Sifat-sifat baik yang mendasari moral disebut sebagai karakter saat diwujudkan dalam bentuk perilaku yang terlihat.

Pendidikan karakter adalah pendekatan langsung pada pendidikan moral, yakni mengajari murid dengan pengetahuan moral dasar untuk mencegah mereka melakukan tindakan tak bermoral dan membahayakan orang lain dan dirinya sendiri. Pengajaran tentang konsep moral yang berhubungan dengan perilaku tertentu dapat disajikan dalam bentuk contoh dan definisi, diskusi dan role playing, atau memberi ganjaran pada murid yang berperilaku benar (Santrock, 2008). Tujuan pendidikan menurut Foerster (dikutip Koesoema, 2007) adalah untuk pembentukan karakter yang terwujud dalam kesatuan esensial antara si subjek dengan perilaku dan sikap hidup yang dimilikinya. Karakter merupakan sesuatu yang mengualifikasi seorang pribadi.

Santrock (2008) mengatakan pendidikan moral kognitif adalah pendekatan yang didasarkan pada keyakinan bahwa murid harus mempelajari hal-hal seperti demokrasi dan keadilan saat moral mereka sedang berkembang. Lickona (1994) percaya adanya keberadaan moral absolute dan bahwa moral absolute 
itu perlu diajarkan kepada generasi muda agar mereka paham betul mana yang baik dan benar. Kohlberg (dikutip Papalia, 2004) menyatakan bahwa, pemikiran moral anak dapat ditingkatkan melalui diskusi dengan orang lain yang penalarannya berada pada tahap yang lebih tinggi. Hubungan memberi dan menerima antar kawan seusia akan memajukan penalaran moral karena dalam hubungan semacam ini anak berkesempatan melakukan peran yang berbeda.

Pendidikan karakter dapat diartikan sebagai bantuan sosial agar individu itu dapat bertumbuh dalam menghayati kebebasannya dalam hidup bersama dengan orang lain dalam dunia (Koesoema, 2007). Santrock (2008) menyatakan bahwa murid yang mengetahui aturan-aturan moral alternatif, mengeksplorasi pendapat, dan kemudian memutuskan sendiri kode moral apa yang terbaik bagi dirinya. Lickona (1992), prinsip dasar pendidikan karakter adalah bahwa apa yang dilakukan individu akan mempengaruhi kinerja komunitas, jadi apa yang dilakukan individu memiliki makna dan berpengaruh bagi perkembangan sekolah. Dalam menjalankan prinsip itu maka nilai-nilai yang diajarkan harus termanifestasikan dalam kurikulum. Lickona, (2004), Tugas para pendidik dan sekolahlah untuk menjadikan manusia menjadi makhluk baik yang beradab dan berbudi luhur.

Pendidikan karakter dalam konteks mikro, berpusat pada satuan pendidikan secara holistik. Satuan pendidikan merupakan sektor utama yang secara optimal memanfaatkan dan memberdayakan semua lingkungan belajar yang ada untuk menginisiasi, memperbaiki, menguatkan, dan menyempurnakan secara terus-menerus proses pendidikan karakter di satuan pendidikan. Pendidikanlah yang akan melakukan upaya sungguh-sungguh dan senantiasa menjadi garda depan dalam upaya pembentukan karakter manusia Indonesia yang sesungguhnya. Pengembangan karakter dibagi dalam empat pilar, yakni kegiatan belajar-mengajar di kelas, kegiatan keseharian dalam bentuk pengembangan budaya satuan pendidikan; kegiatan ko-kurikuler dan/atau ekstra kurikuler, serta kegiatan keseharian di rumah dan masyarakat (Kementerian Pendidikan Nasional, 2010).

Sekolah, adalah lembaga sosial kedua setelah keluarga yang mempunyai peranan penting dalam membentuk karakter dan watak anak. Interaksi anak dengan guru, teman, dan administrator sekolah, akan memperluas pengetahuan dan wawasan anak serta penghayatan mereka mengenal nilai-nilai kehidupan yang penting bagi perkembangan dirinya, baik sebagai pribadi maupun sebagai bagian dari masyarakat yang lebih luas. Proses pendidikan yang dilaksanakan lembaga sekolah tidak dapat diartikan hanya sebagai proses pengetahuan dan keterampilam dari guru ke siswa. Lebih daripada itu, pendidikan yang dilaksanakan harus dapat membentuk watak atau karakter yang lebih baik dari para peserta didik, dan dengan menjadi lebih baik berarti pula bahwa ia akan menjadi lebih bermartabat (Ajisukmo, 2010).

Kementerian Pendidikan Nasional (2010), proses pendidikan karakter tersebut dimulai dari TK/RA berlanjut ke kelas satu SD/MI atau tahun pertama dan berlangsung paling tidak sampai kelas 9 atau kelas terakhir SMP/MTs. Pendidikan karakter di SMA/MA atau SMK/MAK adalah kelanjutan dari proses yang telah terjadi selama 9 tahun. Sedangkan pendidikan karakter di Perguruan Tinggi merupakan penguatan dan pemantapan pendidikan karakter yang telah diperoleh di SMA/MA, SMK/MAK Melalui semua mata pelajaran, pengembangan diri, dan budaya satuan pendidikan mensyaratkan bahwa proses pengembangan Pendidikan karakter mempunyai makna lebih tinggi dari pendidikan moral, karena bukan sekadar mengajarkan mana yang benar dan mana yang salah, lebih dari itu pendidikan karakter menanamkan kebiasaan (habituation) tentang hal yang baik sehingga peserta didik menjadi paham (domain kognitif) tentang mana yang baik dan salah, mampu merasakan (domain afektif) nilai yang baik dan biasa melakukannya (domain perilaku). Jadi pendidikan karakter terkait erat kaitannya dengan habit atau kebiasaan yang terus-menerus dipraktekkan atau dilakukan. 
Badan Penelitian dan Pengembangan Pusat Kurikulum dan Perbukuan (2011), pembelajaran karakter dilaksanakan melalui proses belajar setiap materi pelajaran atau kegiatan yang dirancang khusus. Pengintegrasian pendidikan karakter ke dalam semua materi pembelajaran dilakukan dalam rangka mengembangkan kegiatan intervensi. Yang perlu dilakukan lebih lanjut adalah memastikan bahwa pembelajaran materi pembelajaran tersebut memiliki dampak instruksional dan/atau dampak pengiring pembentukan karakter. Pengintegrasian nilai dapat dilakukan untuk satu atau lebih dari setiap pokok bahasan dari setiap materi pembelajaran. Seperti halnya sikap, suatu nilai tidaklah berdiri sendiri, tetapi berbentuk kelompok. Secara internal setiap nilai mengandung elemen pikiran, perasaan, dan perilaku moral yang secara psikologis saling berinteraksi.

Cara mengintegrasikan nilai-nilai karakter ke dalam materi pembelajaran, antara lain: mengungkapkan nilai-nilai yang ada dalam materi pembelajaran, mengintegrasikan nilai-nilai karakter menjadi bagian terpadu dari materi pembelajaran, menggunakan perumpamaan dan membuat perbandingan dengan kejadian-kejadian serupa dalam hidup para peserta didik, mengubah hal-hal negatif menjadi nilai positif, mengungkapkan nilainilai melalui diskusi dan curah pendapat, menggunakan cerita untuk memunculkan nilai-nilai, menceritakan kisah hidup orang-orang besar, menggunakan lagu-lagu dan musik untuk mengintegrasikan nilai-nilai, menggunakan drama untuk melukiskan kejadian-kejadian yang berisi nilai-nilai, menggunakan berbagai kegiatan seperti kegiatan pelayanan, praktik lapangan melalui klub-klub.

Mahasiswa adalah peserta didik yang terdaftar dan belajar pada Perguruan Tinggi. Perguruan Tinggi dapat menjadi wadah untuk memperoleh dan mengembangan intelektual, kepribadian, dan khususnya dalam melatih keterampilan verbal, kuantitatif, berpikir kritis dan penalaran moral (Montgomery dalam Papalia,Old \& Feldman, 2007). Dalam tahap perkembangannya mahasiswa digolongkan sebagai remaja akhir dan dewasa muda dengan usia rata-rata 18-21 tahun dan 22-24 tahun (Monks dkk., dalam Fibrianti, 2009).

Menurut teori neo-Piaget (dalam Papalia.dkk., 2007) mahasiswa yang dalam tahap perkembangannya telah memasuki dewasa muda, secara kognitif mahasiswa dituntut untuk bisa berpikir abstrak, menalar, atau berpikir reflektif. Bukan hanya sekadar berpikir abstrak, mahasiswa secara kognitif memiliki pemikiran postformal, yang dapat menggabungkan logika, emosi, dan pengalaman praktis dalam memecahkan suatu masalah. Pemikiran mahasiswa berkembang dari pemikiran yang kaku (rigidity) ke pemikiran yang lebih fleksibel dan akhirnya merasa secara bebas dapat memilih (William Pery dalam Papalia dkk., 2007).

\section{Kerangka Berpikir Penelitian}

Misi pembangunan nasional yang memposisikan pendidikan karakter sebagai misi pertama dari delapan misi guna mewujudkan visi pembangunan nasional, sebagaimana tercantum dalam Rencana Pembangunan Jangka Panjang Nasional Tahun 2005-2025, yaitu terwujudnya karakter bangsa yang tangguh, kompetitif, dinamis, berakhlak mulia, dan bermoral berdasarkan Pancasila, yang dicirikan dengan watak dan perilaku manusia dan masyarakat Indonesia yang beragam, beriman dan bertakwa kepada Tuhan Yang Maha. Salah satu strategi pembentukan karakter yang dituangkan dalam Kebijakan Nasional Pembangunan Karakter Bangsa tahun 2010 lewat pendidikan di sekolah. Salah satunya terintegrasi dalam pelajaran Pendidikan Agama dan Kewarganegaraan (PKN).

Karakter bukan sekadar hasil dari sebuah tindakan melainkan secara simultan merupakan hasil dan proses (Santrock, 2008). Kemendiknas (2010), proses pendidikan karakter tersebut dimulai dari TK/RA berlanjut ke kelas satu SD/MI atau tahun pertama dan berlangsung paling tidak sampai kelas 9 atau kelas 
terakhir SMP/MTs. Pendidikan karakter di SMA/MA atau SMK/MAK adalah kelanjutan dari proses yang telah terjadi selama 9 tahun. Sedangkan pendidikan karakter di Perguruan Tinggi merupakan penguatan dan pemantapan pendidikan karakter yang telah diperoleh di SMA/MA, SMK/MAK

Adanya kewajiban sekolah untuk membentuk siswanya agar memiliki karakter yang diprioritaskan pemerintah antara lain tangguh, kompetitif, berakhlak mulia, bermoral, bertoleran, bergotong royong, patriotik, dinamis, berbudaya, dan berorientasi Ipteks berdasarkan Pancasila dan dijiwai oleh iman dan takwa kepada Tuhan Yang Maha Esa, dalam Pendidikan Agama dan Pendidikan Kewarganegaraan, menarik untuk dilihat apakah pendidikan karakter ini dapat membantu mahasiswa semester 1 dalam menghadapi tantangan sebagai mahasiswa baru. Oleh karena itu akan dilihat gambaran karakter mahasiswa semester 1 di Jurusan Psikologi Binus University .

\section{METODE}

\section{Partisipan}

Populasi dalam penelitan ini diambil dari mahasiswa psikologi Binus University semester I (Binusian 2016). Jumlah populasi sebanyak 144 orang, teknik sampel yang diambil adalah purposive sampling, dengan maksud semua populasi diambil semua. Subjek yang berhasil diambil sebanyak 100 orang hal ini disebabkan pada saat kuesioner disebar subjek tidak datang.

Teknik pengumpulan data menggunakan kuesioner, yang akan dibagikan ke subjek. Instrumen penelitian (kuesioner) dikonstruk peneliti dengan menggunakan indikator karakter tangguh, kompetitif, dan melakukan uji validitas dan reabilitas. Pengukurnya menggunakan skala Likert. Instrumen penelitian terdiri dari tiga alat ukur yaitu karakter tangguh, kompetitif, dan dinamis. Indikator tangguh diambil dari Frese, Garst, \& Fay (2007), yaitu keuletan dalam mengatasi rintangan atau hambatan yang dilandasi rasa tanggung jawab terhadap pekerjaannya.

Indikator kompetitif dan dinamis diambil dari Goleman (2005), kompetitif adalah dorongan untuk meningkatkan kualitas diri agar menjadi lebih baik lagi atau memenuhi standar keberhasilan. Sedangkan dinamis adalah optimis dalam memperjuangkan sasaran. Alat ukur tangguh reliabel yaitu sebesar 0,746, Realibilitas alat ukur kompetitif 0,603. Reliabilitas alat ukur dinamis sebesar 0,583.

\section{Desain}

Desain penelitian yang dipakai pada penelitian ini adalah kuantitatif diskriptif untuk mengetahui peran pendidikan Agama dan Kewarganegaraan (PKN) dalam meningkatkan karakter tangguh, kompetitif, dan dinamis.

\section{Prosedur}

Sebelum menyebarkan kuesioner peneliti terlebih dahulu mencari data-data subjek yang akan diambil sampelnya, data tersebut diambil dari biro data universitas yang diteliti. Setelah data calon partisipan didapat, peneliti meminta bantuan dosen pengajar yang waktu itu mengajar di kelas tersebut untuk menyebarkan kuesioner. Dari 150 kuesioner yang disebarkan hanya 100 saja yang terisi. 


\section{Teknik Analisis}

Data penelitian ini diolah menggunakan program SPSS for windows. Metode yang digunakan dengan teknik statistik diskriptif untuk mengetahui gambaran persepsi subjek terhadap Pelajaran Agama dan Pelajaran PKN, persepsi subjek terhadap karakter yang didapat setelah mendapat pelajaran Agama dan pelajaran PKN. Chi-Square T-test digunakan untuk mengetahui hubungan antara karakter dengan jenis dan asal SMA dan hubungan antara karakter dengan persepsi subjek terhadap pelajaran agama dan PKN

\section{HASIL \& ANALISIS}

Pembahasan awal penelitian ini akan melihat bagaimana persepsi subjek terhadap mata pelajaran Pendidikan Agama dan Pendidikan Kewarganegaraan. Hal yang ingin dilihat berdasarkan apa yang telah dijelaskan bahwa dalam pendidikan khususnya pendidikan karakter di sekolah, interaksi antara guru dengan peserta didik sangatlah dekat dan apa yang diterima oleh peserta didik dipengaruhi oleh persepsinya terhadap pelajaran yang diberikan oleh guru. Proses pembelajaran yang terjadi di dalam pendidikan bukan hanya pengalihan ilmu pengetahuan namun juga mencakup perasaan dan kualitas hubungan antara guru dan peserta didik. Perasaan yang dirasakan oleh peserta didik pun dapat mempengaruhi bagaimana ia mempersepsikan suatu mata pelajaran dan pada akhirnya menentukan seberapa banyak isi dari mata pelajaran tersebut ia terima dan dapat diinternalisasikan. Lebih jauh dari itu, perilaku yang selalu dimunculkan guru pun menjadi contoh nyata dalam keseharian yang dapat ditiru dan diterapkan oleh peserta didik. Setelah melihat persepsi peserta didik terhadap mata pelajaran Pendidikan Agama dan Pendidikan Kewarganegaraan maka akan ditelaah lebih lanjut mengenai gambaran karakter tangguh, kompetitif dan dinamis yang dimiliki oleh subjek.

\section{Persepsi Subjek terhadap Pelajaran Agama}

Subjek yang terbanyak mengikuti pelajaran Agama Islam 64 orang (64\%), Katholik 14 orang (14\%), Protestan 9 orang (9\%), Budha 7 orang (7\%), Hindhu 3 orang (3\%), dan lain-lain 1 orang (1\%). Subjek yang menjawab lain-lain mengikuti pelajaran religiusitas bukan pelajaran agama.

Subjek terbanyak mengatakan bahwa belajar Agama di sekolahnya menyenangkan 84\%, dan yang menyatakan pelajaran Agama tidak menyenangkan sebanyak 13\%. Subjek yang menyatakan bahwa pelajaran Agama tidak menyenangkan memberikan keterangan karena guru mata pelajaran tersebut membosankan sehingga subjek sering tidak mengikuti pelajaran tersebut. Subjek yang tidak mendapat Pelajaran Agama di sekolahnya ada 1 orang, pelajaran pengganti agama yang subjek dapatkan adalah religiusitas.

\section{Persepsi Subjek terhadap Pelajaran PKN}

Subjek terbanyak mengatakan bahwa belajar PKN di sekolahnya menyenangkan $55 \%$, dan yang menyatakan pelajaran PKN tidak menyenangkan 45\%.

\section{Persepsi Subjek terhadap Karakter yang didapat Setelah Mendapat Pelajaran Agama}

Subjek terbanyak mengatakan bahwa pelajaran Agama disekolahnya membentuk karakter berakhak mulia sebanyak $35 \%$, bertoleran $31 \%$, bergotong royong $17 \%$, tangguh $5 \%$, dinamis $5 \%$, kompetitif $3 \%$, patriotik 
2\%, lain-lain $2 \%$. Karakter lain yang didapat setelah mendapat pelajaran Agama adalah saling mengenal, saling bersahabat dengan penuh kasih, melakukan hal positif. Subjek yang mengatakan tidak ada tambahan karakter yang didapat karena guru yang mengajarkan membosankan sehingga subjek sering tidak mengikuti pelajaran.

\section{Gambaran Karakter Tangguh, Kompetitif, dan Dinamis pada Diri Subjek}

Subjek terbanyak mempunyai karakter tangguh, berikutnya karakter kompetitif, dan yang terendah memiliki karakter dinamis. Gambaran karakter tersebut dapat dilihat dalam diagram berikut ini:

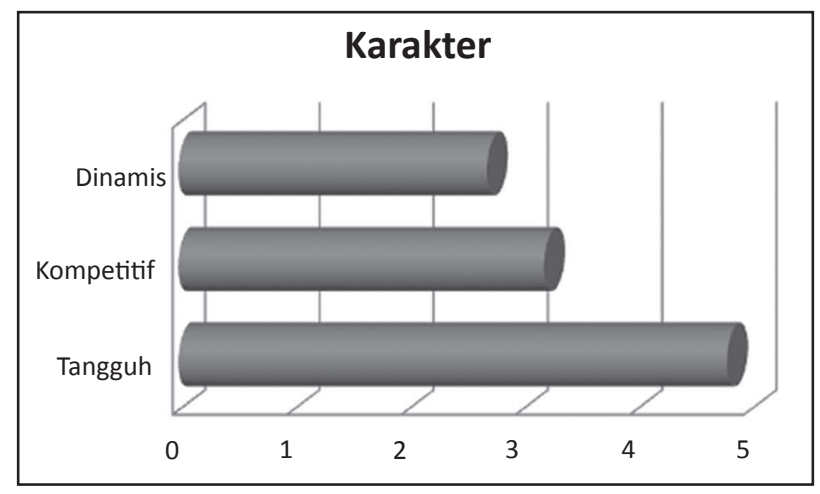

Bagan 1. Gambaran Karakter Dinamis, Kompetitif, dan Tangguh

Karakter tangguh pada diri subjek terbanyak ada di kategori sedang sebesar $54 \%$, berikutnya pada kategori tinggi dan rendah mempunyai nilai yang sama yaitu sebesar $23 \%$. Dengan demikian sebagian besar subjek penelitian berada pada kategori sedang untuk keuletan dalam menghadapi rintangan atau hambatan yang dilandasi rasa tanggung jawab terhadap pekerjaannya.

Karakter kompetitif pada diri subjek terbanyak ada di kategori sedang sebesar $62 \%$, berikutnya pada kategori tinggi $26 \%$, dan terendah ada pada kategori rendah $12 \%$. Hal ini menunjukkan bahwa sebagian besar subjek memiliki daya juang yang cukup untuk mencapai prestasi atau aspirasi yang dimilikinya.

Karakter dinamis pada diri subjek terbanyak ada di kategori sedang sebesar $53 \%$, berikutnya pada kategori tinggi $24 \%$, dan terendah ada pada kategori rendah $23 \%$.

\section{Hubungan antara Karakter dengan Jenis dan Asal SMA}

Dengan mengunakan analisis Chi-Square, karakter tangguh dan karakter dinamis tidak ada hubungannya dengan jenis SMA dan asal SMA subjek. Karakter kompetitif ada hubungannya dengan jenis SMA subjek, tetapi asal SMA tidak ada hubungannya dengan karakter kompetitif. Hasil olah data dapat dilihat dalam tabel berikut ini.

Tabel 1. Hubungan antara Karakter dengan Jenis dan Asal SMA

\begin{tabular}{lll}
\hline \multirow{2}{*}{ Variabel } & \multicolumn{2}{c}{ Chi-Square } \\
\cline { 2 - 3 } & Jenis SMA & Asal SMA \\
\hline Tangguh & $0,591>0,05$ & $0,489>0,05$ \\
Kompetitif & $0,002<0,05$ & $0,195>0,05$ \\
Dinamis & $0,226>0,05$ & $0,193>0,05$ \\
\hline
\end{tabular}




\section{Hubungan antara Karakter dengan Persepsi terhadap Pelajaran Agama dan PKN}

Dengan menggunakan analisis Chi-Square, karakter tangguh, kompetitif, dan dinamis tidak ada hubungannya dengan persepsi subjek tentang pelajaran agama yang menyenangkan dan pelajaran PKN yang menyenangkan.

Tabel 2. Hubungan antara Karakter dengan Persepsi terhadap Pelajaran Agama dan PKN

\begin{tabular}{lll}
\hline \multirow{2}{*}{ Variabel } & \multicolumn{2}{c}{ Chi-Square } \\
& Agama Menyenangkan & PKN Menyenangkan \\
\hline Tangguh & $0,491>0,05$ & $0,757>0,05$ \\
Kompetitif & $0,691>0,05$ & $0,464>0,05$ \\
Dinamis & $0,270>0,05$ & $0,146>0,05$ \\
\hline
\end{tabular}

\section{DISKUSI}

Berdasarkan ketiga karakter yang telah dijabarkan di atas, sebagian besar subjek mahasiswa semester 1 yang baru saja selesai mengenyam pendidikan di sekolah menengah memiliki karakter tangguh, kompetitif dan dinamis pada kategori sedang. Hal ini menunjukkan bahwa mereka memiliki ketiga karakter tersebut namun intensitas yang ada tidak terlalu kuat.

Apabila melihat persepsi peserta didik terhadap mata pelajaran Pendidikan Agama dan Pendidikan Kewarganegaraan, dapat disimpulkan bahwa tidak ada hubungan yang signifikan antara persepsi terhadap kedua mata pelajaran ini dengan karakter yang dimiliki oleh peserta didik. Hal ini menunjukkan bahwa peserta didik tetap memiliki karakter tangguh, kompetitif dan juga dinamis tidak berdasarkan apakah mereka mempersepsikan kedua mata pelajaran tersebut menyenangkan atau tidak menyenangkan.

McCandles (1970 dalam Lerner \& Hultsch, 1983) memiliki pertimbangan bahwa sekolah memiliki fungsi untuk melatih keterampilan dan memiliki budaya untuk mengkomunikasikan pengetahuan dan nilai-nilai. Ia mempercayai bahwa sistem pendidikan menciptakan suatu setting di mana para remaja dapat merasa bahagia dan juga merasa tertantang; sekolah merupakan tempat untuk mengembangkan keoptimalan diri, atribut interpersonal dan memaksimalkan kemampuan seseorang untuk dapat berkontribusi dalam lingkungan sosialnya. Oleh karena itu, kemungkinannya pembentukan karakter khususnya karakter tangguh, kompetitif dan dinamis dapat saja berkembang dengan baik dikarenakan oleh situasi dan kondisi sekolah secara keseluruhan dan bukan secara khusus melalui mata pelajaran Pendidikan Agama dan Pendidikan Kewarganegaraan.

\section{SIMPULAN \& SARAN}

\section{Simpulan}

Subjek terbanyak mempunyai karakter tangguh, berikutnya karakter kompetitif, dan yang terendah memiliki karakter dinamis. Sebagian besar subjek memiliki karakter tangguh, kompetitif dan dinamis pada kategori sedang. Pada persepsi peserta didik terhadap mata pelajaran Pendidikan Agama dan Pendidikan 
Kewarganegaraan, dapat disimpulkan bahwa tidak ada hubungan yang signifikan antara persepsi terhadap kedua mata pelajaran ini dengan karakter yang dimiliki oleh peserta didik.

\section{Saran}

Saran untuk penelitian selanjutnya:

1. Melihat berbagai macam faktor lain yang dapat mempengaruhi pembentukan karakter peserta didik seperti: persepsi terhadap situasi dan kondisi sekolah, metode yang digunakan guru untuk mengajarkan mata pelajaran Pendidikan Agama dan Pendidikan Kewarganegaraan, persepsi guru terhadap mata pelajaran Pendidikan Agama dan Pendidikan Kewarganegaraan, dan lain-lain.

2. Menelaah lebih dalam mengenai metode pengajaran yang diberlakukan di dalam sekolah tertentu.

\section{DAFTAR PUSTAKA}

Ajisukmo, C. (2010). Pendidikan karakter. Conference Proceeding: Konferensi Nasional dan Workshop Asosiasi Psikologi Pendidikan Indonesia "Peran Pendidikan dalam Pembangunan Karakter Bangsa", hlm: 2

Badan Penelitian dan Pengembangan Pusat Kurikulum dan Perbukuan (2011), Panduan Pelaksanaan Pendidikan Karakter.

Berkowitz, M., \& Bier., M.C. (2004). Research based character education, Journal of Educational Research, hlm. 73-76.

Fibrianti, D. I. (2009). Hubungan antara Dukungan Sosial Orangtua dengan Prokrastinasi Akademik dalam Menyelesaikan Skripsi pada Mahasiswa Fakultas Psikologi Universitas Diponegoro Semarang.pdf. (Tugas akhir tidak dipublikasikan). Fakultas Psikologi Universitas Diponegoro.

Frese, M., Garst, H., \& Fay D. (2007). Making things happen: Reciprocal relationships between work characteristics and personal Initiative in a four-wave longitudinal structural equation model. Journal of Applied Psychology, 92(4), 1084-1102.

KEMDIKNAS (2010), Kerangka Acuan Pendidikan Karakter Tahun Anggaran 2010.

Koesoema, D. A. (2007). Pendidikan karakter: Strategi mendidik anak di zaman global. Jakarta: Grasindo.

Lerner, R. M., \& Hultsch, D. F. (1983). Human Development A Life - Span Perspective. United States: McGraw-Hill, Inc.

Lickona, T. (1992). Educating for character: How our schools can teach respect and responsibility. NY: Bantam.

Lickona, T. (2004), Character matter: How to help our children develop good judgment, integrity, and other essential virtues. NY: Touchstone.

Milson. A. J. \& Mehlig. (2002). Elementary school teacher's sense of efficacy for character education. The journal of Education Research, hlm. 47. 
Mini, R. A. P. (2010). Perkembangan Moral sebagai dasar pendidikan karakter anak. Makalah dalam Konferensi Nasional dan Workshop Asosiasi Pendidikan Indonesia. Malang.

Goleman, D. (2005). Working with emotional intelligence: kecerdasan emosi untuk mencapai puncak prestasi. Jakarta: PT Gramedia Pustaka Utama.

Papalia, D. E. (2004). Human development. $9^{\mathrm{h}}$ ed. Boston: McGraw Hill.

Papalia, D. E., Old, S. W., \& Feldman, R.D. (2007). Human Development. $10^{\text {th }}$ ed. New York: McGraw Hill.

Pemerintah RI. (2010), Buku Induk Kebijakan Nasional Pembangunan Karakter Bangsa Tahun 2010 - 2025

Santrock, J. W. (2008). Educational Psychology (3 ${ }^{\text {th }}$ ed.) Boston: Mc Graw Hill.

Saurina, N. M \& Pandia, S.S.W. (2012), Dampak kurikulum terhadap ketangguhan siswa (Penelitian di SMP dengan standar Nasional dan Standar Internasional, Procedding Simposium pendidikan karakter, hlm. 51.

Stolz, P.G. (2000) Adversity Quotient: Mengubah hambatan menjadi peluang. Jakarta: Grasindo.

\section{Internet}

Bappenas (2013). UU No. 17 Tahun 2007 tentang Rencana pembangunan jangka panjang nasional tahun 2005-2025, diunduh 18 Februari 2013, dari http://www.bappenas.go.id/node/123/26/uu-no-17-tahun2007-tentang-rencana-pembangunan-jangka-panjang-nasional-tahun-2005-2025-/ 